\title{
Mobile Learning Via SMS Among Distance Learners: Does Learning Transfer Occur?
}

\author{
doi:10.3991/ijim.v4i3.1180 \\ Aznarahayu Ramli, Issham Ismail, and Rozhan Md. Idrus \\ Universiti Sains Malaysia, Penang, Malaysia
}

\begin{abstract}
The purpose of this study is to determine whether learners are willing to transfer learning in this mobile learning environment via SMS. The reason for this is to measure the effectiveness of the new method used in learning and education especially in distance education field. For this reason, students' responses are gathered which looked at three factors namely learner characteristic, learning design and learning environment. The data are gathered through a survey research design with questionnaires using five-point likert scale. The questionnaires was administered for 105 distance education students from four courses including Bachelor of Science, Bachelor of Arts, Bachelor of Social Science and Bachelor of Management. The Rasch Model Analysis was used to measure these dimensions. Rasch Model is a one-parameter logistic model within item response theory (IRT) whereby the amount of a given latent trait in a person and the amount of that same latent trait reflected in various items can be estimated independently yet still compared explicitly to one another. The result of the study showed that learning transfer occurred and being influenced most by learner's characteristics especially in term of their motivation as well as their perceive utility/value of the SMS learning to their job and academic performances.
\end{abstract}

Index Terms-Mobile Learning, SMS, Distance Education, Learning Transfer.

\section{INTRODUCTION}

The learning process slowly makes it away outside the classroom. The technology advancement has witnessed the emerging trend in learning and education both in real life and virtually. With the quick advance in mobile technologies and devices, comes the birth of new term in learning and education - mobile learning. In a study of this trend Muyinda [1], mobile learning is well positioned to champion these innovations.

Mobile learning becomes a new learning experience in the open and distance learning environments [2]. Quinn [3] defines mobile learning as learning through mobile computational devices while Shepherd [4] stated that ' $M$ Learning is not just electronic, it's mobile.' Another definition by Trifonova [5] is defined mobile learning as a field which synchronizes two capable fields - mobile computing and E-learning.

The capability of mobile technologies in delivering and enhancing learning are quite difference between developed countries and developing countries. Traxler and Dearden [6] in their study found that in developed countries, mobile technologies are able to assist learning and education compared to developing countries due to the factors of their mains electricity, computer hardware and internet connectivity are stable, reliable, cheap and abundant. For example, in developed countries such as US and Europe, the Windows and Palm-base personal digital assistants (PDA) are widely used to provide media-rich educational content [7]. However, in developing Asian countries such as Malaysia, the high cost of ownership and connection of the devices makes it impossible to apply those devices in learning and educational context. In this case, the more accessible and popular mobile or cell phones can be used instead.

\section{A. Background of the Study}

The penetration rate of mobile phones in Malaysia has exceeded $100.0 \%$. This occurs because of multiple subscriptions by the citizens. This phenomenon shows a significant growth of mobile phone adoption in Malaysia and the Malaysians are keen in owning and using mobile phone in which the data provided by Malaysian Communications and Multimedia Commission [8] showed that $90.3 \%$ of Malaysians own mobile phones. The data also showed that $50.4 \%$ of the mobile phones users sent more than 5 SMS per day.

The advantages of mobile devices such as limitless mobility and small size can bring new dimensions to the learning processes of the students especially for distance learning students who are always on the go and on the move [9]. Jacob and Issac [10] in their study, resounding the facts that, the goal of mobile learning is to facilitate learning and hoping that in future, learning can be ubiquitously with the aid of wireless convergence. They also addressed the issue regarding the challenges of mobile learning includes the instructional strategies, learning content and design that promotes to continuous learning activity.

Learners should experience mobile learning in order to know the learning process through that method. The purpose of the learning experience is for the learners to gain skills and knowledge through learning process and / or for there to be a change in attitudes and beliefs [11]. Huczynski and Lewis [12] also reported that the learning experience that learners gained will promote to the motivation to transfer learning. Transfers of learning refers to a situation whereby a student learns behaviors, skills, and knowledge in one context and applies them in another context. In which it means that, transfer of learning occurs when learners are able to apply what they learn through mobile learning in their study and job.

\section{B. Purpose of the Study}

The purpose of this study is to determine whether learners are willing to transfer learning in this mobile 
learning environment via SMS. The reason for this is to measure the effectiveness of the new method used in learning and education especially in distance education field. For this reason, students' responses are gathered which looked at three factors namely learner characteristic, learning design and learning environment. These three main factors have been proposed by Baldwin \& Ford [13], the former researchers in learning transfer study who suggested that transfer factors would be represented by three domains: trainee characteristics, training design and work environment.

\section{Research Methodology}

\section{A. Instrument}

Questionnaire is used as the data collection instrument for this study. It is divided into two sections which are demographics questions and likert-type questions. A cover letter explaining the purpose of the questionnaire is also attached to the questionnaire. The demographic questions capture information of the respondents regarding gender, age, marital status, income level, and mobile device ownership. The likert-type questions are divided into three sections which are Learners' Characteristics, Learning Design and Learning Environment. Other than the questions on demographic information, all other questions used the five-point Likert Scale ranging from 1 to 5 , in which 1 is for 'strongly disagree', 2 for 'disagree', 3 for 'neutral', 4 for 'agree' and 5 for 'strongly agree'.

The items used in this study are adopted from the study conducted by Holton et al., [14]. Their instrument offers several key strengths as it was based on a very large and extremely diverse sample and also builds on the results of several previous research efforts as well as followed generally accepted instrument development process. Thus, it provides a high level of confidence that the items being adopted will work well in this new learning environment (Mobile Learning via SMS). Holton et al., in this study also proposed that future research should combine the items with other instruments to assess transfer result more completely. Thus, in this study, the researchers also added some others items that are more focus on mobile learning environment which have been developed by University's experts.

\section{B. Data Collection Procedure}

A total of 119 questionnaires were distributed to students from four difference courses in School of Distance Education, Universiti Sains Malaysia (USM) which are Bachelor of Science, Bachelor of Arts, Bachelor of Social Science and Bachelor of Management. From the total, 105 questionnaires were returned hence making a response rate of 88 per cent. The high response rate could be attributed to the fact that the questionnaires are being sent via email hence making it more convenient, faster and time savvy. The responses are 43.8 percent from second year students, 53.3 percent from third year students and 2.9 percent from fourth year students.

This mobile learning assisted course was introduced in the second semester of the 2008/2009 academic session and covered two subjects for Management students which are Financial Principle for second year and International Business for third year. Besides that, for Science students specifically Physics students, the course that covered in this mobile learning assisted course are Mechanics and
Optics. Both are for second year students. Two courses that covered for Economic students are Money and Banking for second year and Quantitative Economy for third year. During the duration of this program which was conducted for three months (February 2009 to April 2009), the registered students received text message once a day regarding their subject matter. This project is a preliminary project conducted to gather students' acceptance and readiness towards learning via mobile phone. Thus, at this stage it involves a one-way-communication whereby the students only can receive an SMS per day with no permission response back to the sender. The information being sent to the students are including short notes, terms, problem solving, equation, etc. related to their subject matter.

\section{Data Analysis and Findings}

Data for the study were collected using a survey research design. Questionnaires were sent out to 119 participants and 105 were returned hence making a response rate of 88 per cent. Based on the 105 usable responses, data for demographic were analyzed using Statistical Package for Social Science (SPSS) Version 12.0, while for the likert type questions, the RASCH Measurement Model were used to come out with the certain interpretation. RASCH Model is a one-parameter logistic model within item response theory (IRT) in which the amount of a given latent trait in a person and the amount of that same latent trait reflected in various items can be estimated independently yet still compared explicitly to one another.

\section{RESULTS AND DISCUSSION}

\section{A. Frequency Analysis of Respondents}

For the demographic, we interpreted the data based on frequency analysis. Frequency Analysis is the convenience and understandable way of looking at different value of variables. The items measured for this study includes Gender, Age, Marital Status, Income Level and Mobile Device Ownership. The results of frequency analysis is shown in Table I.

TABLE I.

FREQUENCY ANALYSIS OF RESPONDENTS

\begin{tabular}{|l|c|c|}
\hline \multicolumn{1}{|c|}{ Items } & Frequencies & Percentage \\
\hline Gender & & \\
\hline Male & 31 & 29.5 \\
\hline Female & 74 & 70.5 \\
\hline Age & & \\
\hline 20-29 years & 44 & 41.9 \\
\hline 30-39 years & 46 & 43.8 \\
\hline 40-49 years & 12 & 11.4 \\
\hline 50 years and above & 3 & 2.9 \\
\hline Marital Status & & \\
\hline Single & 49 & 46.7 \\
\hline Married & 53 & 50.5 \\
\hline Single Parent & 3 & 2.9 \\
\hline Income Level & 22 & \\
\hline Below RM1500 & 28 & 21.0 \\
\hline RM1500-RM2000 & 24 & 22.9 \\
\hline RM2001-RM2500 & 15 & 14.3 \\
\hline RM2501-RM3000 & 16 & 15.2 \\
\hline RM3001-RM3500 and above & & \\
\hline Mobile Device Ownership & 36 & 91.4 \\
\hline Mobile Phone & 6 & 2.9 \\
\hline PDA/Pocket PC/Palmtop & & 5.7 \\
\hline Both & 3 & \\
\hline
\end{tabular}




\section{B. Item/Person Misfit Order Table}

The item and person misfit value is also helpful in this study. The results represented the validation of the instrument whether suitable or not becoming as a tool in data collection [15]. In the other words, its aim is to determine whether the instrument used is a valid tool to utilize for data collection. This can be achieved by checking the unidimensionity of the items. Outfit is the outside factors that influence the items or variables while infit represent the "off-variable noise" that could have an impact on the items or variables. According to Fox [16], any items fall within the infit and outfit limit of 0.6 to 1.5 is considered acceptable. However, for Bond and Fox [17] if the sample is less than 500 participants, the acceptable value of outfit range are from 0 to 1.3. For this study, Table II measures the items of the variables fit the expectations of the RASCH Model.

Any items that fall outside the acceptable range are considered to be invalid for the reason that the respondents viewed the items differently than that intended by the researcher [18]. Out of 13 items being analyzed, 6 items have been rejected for the reasons they are fall outside the acceptable range. All the 6 items are presented in Table III.

TABLE II.

ITEM/PERSON MISFIT TABLE

\begin{tabular}{|c|c|c|c|}
\hline Item & Description & $\begin{array}{c}\text { Infit } \\
\text { MNSQ }\end{array}$ & $\begin{array}{l}\text { Outfit } \\
\text { MNSQ }\end{array}$ \\
\hline L4 & $\begin{array}{l}\text { My job performance improves when I } \\
\text { apply new things that I have learned }\end{array}$ & 1.34 & 1.33 \\
\hline L5 & $\begin{array}{l}\text { I am confident in my ability to use newly } \\
\text { learned skills on the job }\end{array}$ & 1.26 & 1.30 \\
\hline L7 & $\begin{array}{l}\text { I would take another mobile learning } \\
\text { assisted course if relevant to my learning } \\
\text { needs }\end{array}$ & 0.78 & 0.75 \\
\hline L9 & $\begin{array}{l}\text { Mobile learning has helped me pace my } \\
\text { studies in my distance education course }\end{array}$ & 0.72 & 0.70 \\
\hline D10 & $\begin{array}{l}\text { The sequential presentation of lesson via } \\
\text { SMS assisted in my studies }\end{array}$ & 0.70 & 0.69 \\
\hline D11 & $\begin{array}{l}\text { Course learning objectives can be met by } \\
\text { mobile learning }\end{array}$ & 1.10 & 1.08 \\
\hline D15 & $\begin{array}{l}\text { The daily SMS messages assisted in my } \\
\text { studies greatly }\end{array}$ & 0.71 & 0.69 \\
\hline D17 & $\begin{array}{l}\text { Using mobile learning, it is easy for me to } \\
\text { access course content }\end{array}$ & 0.77 & 0.77 \\
\hline D18 & $\begin{array}{l}\text { I can easily remember the term that I } \\
\text { received on my mobile phone }\end{array}$ & 0.84 & 0.84 \\
\hline E21 & $\begin{array}{l}\text { My colleagues encourage me to use the } \\
\text { skills and knowledge I have learned in my } \\
\text { job }\end{array}$ & 1.30 & 1.35 \\
\hline E22 & $\begin{array}{l}\text { My superior sets goals for me that encour- } \\
\text { age me to apply my learning on the job }\end{array}$ & 1.21 & 1.16 \\
\hline E24 & $\begin{array}{l}\text { My workload allows me time to try the } \\
\text { new things I have learned }\end{array}$ & 1.09 & 1.08 \\
\hline E25 & $\begin{array}{l}\text { The resources needed for me to be able to } \\
\text { apply what I've learned will be available } \\
\text { to me after learning session }\end{array}$ & 0.99 & 1.08 \\
\hline E26 & $\begin{array}{l}\text { I get feedback from people about how } \\
\text { well I am applying what I've learned in } \\
\text { my study }\end{array}$ & 1.21 & 1.22 \\
\hline
\end{tabular}

TABLE III.

ITEM FALL OUTSIDE THE ACCEPTABLE RANGE

\begin{tabular}{|l|l|}
\hline Item & \multicolumn{1}{|c|}{ Description } \\
\hline L1 & $\begin{array}{l}\text { Before I further my study, I had a good understanding of how } \\
\text { learning and education would fit my job-related development. }\end{array}$ \\
\hline L3 & It is waste for me if I do not utilize my learning. \\
\hline D16 & $\begin{array}{l}\text { Receiving the SMS while at work (or anywhere) is not an } \\
\text { inconvenience to me. }\end{array}$ \\
\hline D19 & $\begin{array}{l}\text { I can easily remember the term that I received on my mobile } \\
\text { phone }\end{array}$ \\
\hline E23 & $\begin{array}{l}\text { My superior opposes the use of the techniques I've learned in } \\
\text { my study. }\end{array}$ \\
\hline E30 & Does the system offer more than face-to-face meeting? \\
\hline
\end{tabular}

\section{Variable Map}

From the result in item and person misfit analysis, the data then being analyzed and interpret in Variable Map. This is to reveal what are factors among the acceptable items that are mostly influence students' willingness to transfer learning in a mobile learning environment. Variable map is another visual guide to information regarding relative scales [15]. It is used to present the items by ranking them according to the level of difficulty to endorse as well as presenting the respondents by ranking them according to their willingness to endorse the items. In this study, items which are easiest or favorable to endorse represented the main factors influencing students' willingness to transfer learning. The results are showed in Figure 1.

The result in red oval in Figure 1 shows items are ranked from least factors influencing learning transfer (at the top) to the crucial factors influencing learning transfer (at the bottom). The result on the other side of the figure showed the ID of the respondents who responded to each items. Figure 1 provided certain interpretations for this study.

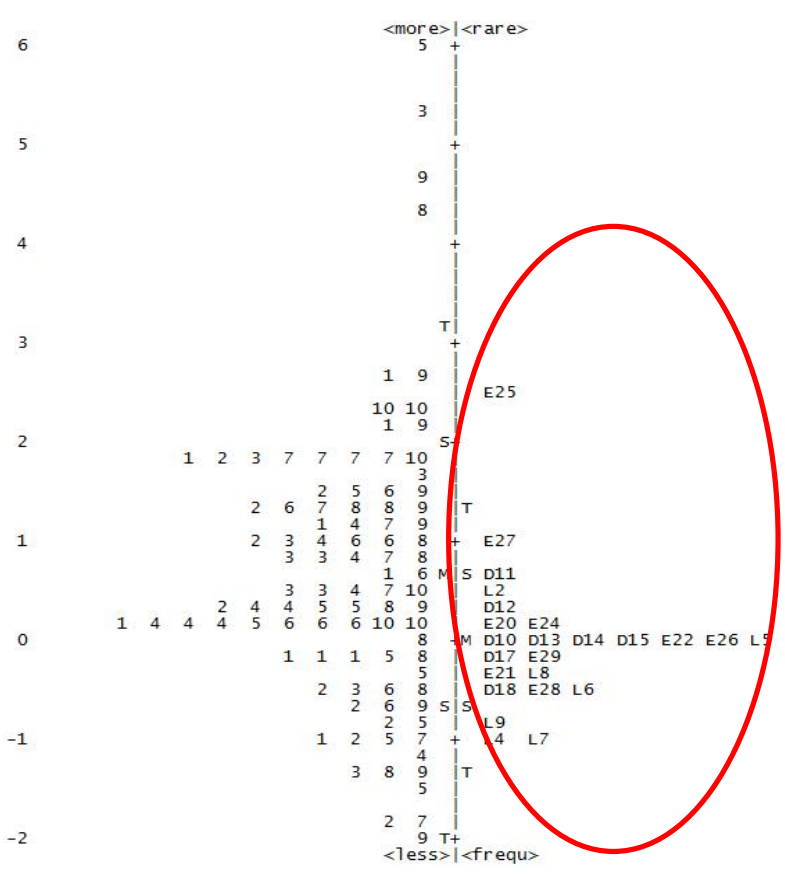

Figure 1. Variable Map 
Result in Figure 1 showed that item L4, L7 and L9 are the crucial factors influencing students' willingness to transfer learning. These three items represented Learners' Characteristics. Thus, it showed us that learner's characteristics are the most influential factors in learning transfer.

\section{Learner's Characteristics}

The result from this study showed that the factor that mostly influent learning transfer via SMS is the learner's characteristics and it is consistent with previous literature on psychology which stated that individual's ability and motivation which are referred to learner's characteristics are the primary factor that influences learning transfer [19].

Item L7 which is "I would take another mobile learning assisted course if relevant to my learning needs" measured learner's motivation to transfer learning via SMS. Learning motivation as defined by Tannenbaum \& Yukl [20] is the learner's intensity and persistence of efforts that they apply in learning-oriented improvement activities, before, during and after learning. There are two motivation-relevant constructs that have been examined in previous research which are pre-training motivation [21] and motivation to learn [22] [23]. The study conducted by Facteau et al. [24] found the correlation between pretraining motivation and training transfer while Quinones [23] found the motivation to learn as the key principle in linking pre-training characteristics and training outcomes. Noe [20] on the studies in military settings found that motivation to learn have an impact on training effectiveness.

In this study, the result showed that learners are willing to take another mobile learning assisted courses if the courses are relevant to their learning needs. This indicates that most of the learners are motivated to continue this course via SMS and allowing the learning transfer to take place. However, their motivation level depends on the courses whether relevant or not to their learning needs. This means, for other courses via this method, they should be tailoring to learner's need and preferences in order to enhance their learning transfer.

Item L4 and L9 which are "My job performance improves when I apply new things that I have learned" and "Mobile learning has helped me pace my studies in my distance education course" separately, measured learner's perceiveness of utility / value of learning via SMS. Previous research found that learner's perceived utility or value of the learning program can influence learning transfer. This has been proved by the study conducted by Baumgartel et al. [25] which showed that managers who believe in the utility or value of the training are more likely to apply the skills learned in training. Axtell et al. [26] on the other hand found that learners who perceived training as relevant had higher levels of immediate skill transfer. Thus, Baldwin \& Ford [13]; Clark et al. [27] have come to the conclusion that, in order for the learners to highly transfer the learning, they should perceive the new knowledge and skills will improve their performance in future.

The results in figure 1 showed that most of the learners believed in the mobile learning potential in improving their performance in their job as well as their study. The result also showed that the learners are interested and happy in using mobile learning as the system assists them in learning process by improving their academic perform- ance and effectiveness. Because of that, it indicated that, when the learners perceived the skills learned via SMS as valuable, they are more willing to transfer the learning. In this study, most learners perceived mobile learning course as the method of learning that can improve their performance in their study as well as their jobs. These influence them to continue mobile learning in the future and affect the mobile learning field positively.

\section{Learning Design}

Learning design has become another group of factors that could influence learning transfer whether directly or indirectly. Figure 1 showed that item D18 is the most acceptable item for learning design. Item D18 which is " $I$ can easily remember the term that I received on my mobile phone" is referred to the content relevant of the SMS learning. These questions revealed learner's perception regarding the content of the SMS learning. Bates [28] stated that for transfer to occur, the goals and materials for learning should be content valid. The last decade has proven that the content relevance is correlating with transfer outcomes [14] [29] [30]. Consistent with previous study done by Axtell et al. [26], found that content validity was highly correlated with transfer. On the other hand, Yamnill \& McLean [31] in the study of Thai managers found that the primary factor in predicting trainee perceptions of successful transfer is the content relevance.

In this study, the terms being used to delivered message and learning contents to the learners via SMS are content valid. This is because, most of the learners agreed that they can easily remember the terms and it also showed that the terms are understandable and relevant. The result also indicated that, learning design also becoming one of the factors that should be considered in influencing learning transfer via SMS. The more attention being taken in the learning design especially the contents, the more learning transfer could occur.

\section{Learning Enviroment}

The third factor that was indentified in this study is learning environment. Learning environment was said to be a factor that influenced learning transfer by supervisory support and opportunity to perform [13]. As the result showed in Figure 1, items E28, E21 and E22 are the acceptable items for learning environment. Several studies explain the relationship between learning environment and learning transfer [32] [21]. These studies which supported previous both empirical and qualitative studies [33] [34] [35] [36] revealed the role of supervisory support in a positive aspect of influencing learning transfer.

Items E21 and E22 which are "My colleagues encourage me to use the skills and knowledge I have learned in my job" and "My superior sets goals for me that encourage me to apply my learning on the job" measured the learner's perception of support they received from their supervisors and also their colleagues. Support from peers and colleagues have proven to be the most influential factor in learning transfer than supervisory support [24]. In the study conducted by Chiaburu \& Marinova [21], among individual and organization support for transfer, peer support having a highly significant relationship with learning transfer. It is consistent with this study on SMS learning whereby result from Figure 1 showed that item for peer support (E21) is situated in the more acceptable rank than item for supervisory support (E22). On the other 
hand, item E28 which is "I would like to see the SMS learning to be used in next semester as well" supported previous items by showing that with the support received from supervisors and peers, there open a good environment for learning via SMS. Thus, most of the learners are excited to continue the learning via SMS in future.

\section{CONCLUSION}

The study has confirmed that learning transfer is yet to occur in mobile learning via SMS environment. Learner's characteristics especially in term of learner's motivation and learner's perceived utility/value in improving performance are proved to be the most influential factors in promoting learning transfer. Thus, learners must be motivated to learn and apply what they learned so that they could believe in SMS learning process and in improving their performance in their study and job. Besides that, there are also certain criteria of learning design that should be looking at in order for learning transfer to occur. They are regarding the content of the SMS learning being delivered to the learners which means, the learning contents via SMS should be designed properly especially concerning the terms, language, and the sequential presentation of the contents. Most importantly, the contents should be understandable and easy to be remembered by the learners. Last but not least, the support from supervisors and peers act as the unbeatable factors in enhancing learning transfer in this mobile learning environment. Responses and feedback from people around them could encourage learners to apply what they learned into their studies and jobs.

\section{ACKNOWLEDGMENT}

This work was supported by Universiti Sains Malaysia under RU grant and USM Fellowship scheme. A grateful appreciation goes to Universiti Sains Malaysia for the supports.

\section{REFERENCES}

[1] Muyinda, P. B. (2007). MLearning: Pedagogical, technical and organization hypes and realities. Campus-Wide Information Systems, 24 (2), 97-104. doi:10.1108/10650740710742709

[2] Safie, N. (2004). The use of Short Messaging System (SMS) as a supplementary learning tool in Open University Malaysia (OUM). $18^{\text {th }}$ Annual Conference Association of Asian Open Universities (AAOU), 27 November - 30 November, 2004, Shanghai, China, pp. 1-11

[3] Quinn, C. (2000). MLearning: Mobile, Wireless and In-YourPocket Learning. Line Zine Magazine, http://www.linezine.com/ 2.1/features/cqmmwiyp.htm

[4] Shepherd, C. (2001). M is for Maybe. Tactix: Training and Communication Technology in Context, http://www.fastrakconsulting.co.uk/tactix/features/mlearning.htm

[5] Trifonova, A. (2003). Mobile Learning-Review of Literature. Technical Report for Department of Information and Communication Technology, University of Trento.

[6] Traxler, J. \& Dearden, P. (2005). The Potential for Using SMS to Support Learning and Organisation in Sub-Saharan Africa. Proceedings of Development Studies Association, http://www.asp2.wlv.ac.uk

[7] Ramos, A. J. \& Trinona, J. (2008). Production of SMS Materials in Distance Education. PANdora Distance Education Guidebook, (eds)

[8] Malaysian Communications and Multimedia Commission (2008). Hand phone users survey 2007. Retrieved August 25, 2009, from http://www.skmm.gov.my
[9] Kinshuk, Suhonen, J., Sutinen, E. \& Goh, T. (2003). Mobile Technologies in Support of Distance Learning. The Asian Society of Open and Distance Education, 1 (1), 60-68

[10] Jacob, M. S. \& Issac, B. (2008). The Mobile Devices and its Mobile Learning Usage Analysis. Proceedings of the International MultiConference of Engineers and Computer Scientists.

[11] Seyler, D. L., Holton, E. F., Bates, R. A., Burnett, M. F. \& Carvalho, M. A. (1998). Factors affecting motivation to transfer training. International Journal of Training and Development, 2 (1). doi:10.1111/1468-2419.00031

[12] Huczynskij, A. A. \& Lewis, W. (2007). An Empirical Study into the Learning Transfer Process in Management Training. Journal of Management Study, 17 (2), 227-240. doi:10.1111/j.14676486.1980.tb00086.x

[13] Baldwin, T. T., \& Ford, J. K. (1988). Transfer of training: A review and directions for future research. Personnel Psychology, 41, 63-105. doi:10.1111/j.1744-6570.1988.tb00632.x

[14] Holton, E. F., Bates, R., \& Ruona,W. E. A. (2000). Development of a generalized learning transfer system inventory. Human Resource Development Quarterly, 11(4), 333-360. doi:10.1002/ 1532-1096(200024)11:4<333::AID-HRDQ2>3.0.CO;2-P

[15] Ren, W., Bradley, K.D., \& Lumpp J.K. (2008). Applying the Rasch Model to evaluate an Implementation of the Kentucky Electronics Education Project. J Sci Educ Technol, 17, 618-625. doi:10.1007/s10956-008-9132-4

[16] Fox, C. (1999). An introduction to the partial credit model for developing nursing assessments. Journal of Nursing Education, 34 (8), 340

[17] Bond, T. \& Fox, C. (2001). Applying Rasch model: fundamental measurement in the human sciences. Mahwah, NJ: Lawrence Erlbaum Associates

[18] Bradley, K. D., Cunningham, J. D., Haines, R. T., Harris, Jr. W. E., Mueller, C. E., Royal K. D., Sampson, S. O., Singletary, G. \& Weber, J. (2006). Constructing and evaluating measures: Applications of the Rasch measurement model. Symposium presented at the Mid-Western Educational Research Association Annual Meeting, Columbus, $\mathrm{OH}$, pp. 1-54

[19] Sackett, P. R., Gruys, M. L., \& Ellingson, J. E. (1998). Ability personality interactions when predicting job performance. Journal of Applied Psychology, 83(4), 545-556. doi:10.1037/00219010.83.4.545

[20] Tannenbaum, S. I., \& Yukl, G. (1992). Training and development in work organizations. Annual Review of Psychology, 43, 399441. doi:10.1146/annurev.ps.43.020192.002151

[21] Chiaburu, D. S., \& Marinova, S. V. (2005). What predicts skill transfer? An exploratory study of goal orientation, training selfefficacy and organizational supports. International Journal of Training and Development, 9, 110-123. doi:10.1111/j.14682419.2005.00225.x

[22] Noe, R. A. (1986). Trainee attributes and attitudes: Neglected influences on training effectiveness. Academy of Management Review, 11, 736-749. doi:10.2307/258393

[23] Quinones, M. A. (1995). Pretraining context effects: Training assignment as feedback. Journal of Applied Psychology, 80, 226238. doi:10.1037/0021-9010.80.2.226

[24] Facteau, J. D., Dobbins, G. H., Russell, J. E. A., Ladd, R. T., \& Kudisch, J. D. (1995). The influence of general perceptions of the training environment on pre-training motivation and perceived training transfer. Journal of Management, 21, 1-25. doi:10.1016/0149-2063(95)90031-4

[25] Baumgartel, H. J., Reynolds, M. J. I., \& Pathan, R. Z. (1984). How personality and organizational climate variables moderate the effectiveness of management development programmes: A review and some recent research findings. Management and Labour Studies, 9(1), 1-16.

[26] Axtell, C. M., Maitlis, S., \& Yearta, S. K. (1997). Predicting immediate and longer term transfer of training. Personnel Review, 26(3), 201-213. doi:10.1108/00483489710161413

[27] Clark, S. C., Dobbins, G. H., \& Ladd, R. T. (1993). Exploratory field study of training motivation: Influence of involvement, credibility, and transfer climate. Group \& Organization Management, 18, 292-307. doi:10.1177/1059601193183003 
[28] Bates, R. A. (2003). Managers as transfer agents: Improving learning transfer in organizations. San Francisco, CA: Jossey Bass.

[29] Lim, D. H., \& Morris, M. L. (2006). Influence of trainee characteristics, instructional satisfaction, and organizational climate on perceived learning and training transfer. Human Resource Development Quarterly, 17(1), 85-115. doi:10.1002/hrdq.1162

[30] Rodriguez, C. M., \& Gregory, S. (2005). Qualitative study of transfer of training of student employees in a service industry. Journal of Hospitality \& Tourism Research, 29, 42-66. doi:10.1177/1096348004270753

[31] Yamnill, S., \& McLean, G. N. (2005). Factors affecting transfer of training in Thailand. Human Resource Development Quarterly, 16(3), 323-344. doi:10.1002/hrdq.1142

[32] Awoniyi, E. A., Griego, O. V., \& Morgan, G. A. (2002). Personenvironment fit and transfer of training. International Journal of Training and Development, 6(1), 25-35. doi:10.1111/14682419.00147

[33] Brinkerhoff, R. O., \& Montesino, M. U. (1995). Partnerships for training transfer: Lessons from a corporate study. Human Resource Development Quarterly, 6(3), 263-274. doi:10.1002/hrdq.3920060305

[34] Broad, M. L., \& Newstrom, J. W. (1992). Transfer of training: Action packed strategies to ensure high payoff from training investments. Reading, MA: Addison-Wesley.

[35] Burke, L. A., \& Baldwin, T. T. (1999). Workforce training transfer: A study of the effect of relapse prevention training and transfer. Human Resource Management, 38(3), 227-243. doi:10.1002/(SICI)1099-050X(199923)38:3<227::AIDHRM5>3.0.CO;2-M
[36] Clarke, N. (2002). Job/work environment factors influencing training effectiveness within a human service agency: Some indicative support for Baldwin and Fords' transfer climate construct. International Journal of Training and Development, 6(3), 146162. doi:10.1111/1468-2419.00156

\section{AUTHORS}

Issham Ismail is with the School of Distance Education, Universiti Sains Malaysia, Minden, Pulau Pinang, 11800 Malaysia (e-mail: issham@usm.my).

Aznarahayu Ramli is a student under the School of Distance Education, Universiti Sains Malaysia, Minden, Pulau Pinang, 11800 Malaysia and currently furthering her Masters Degree (e-mail: aznarahayu@gmail.com)

Rozhan M. Idrus is with the School of Distance Education, Universiti Sains Malaysia, Minden, Pulau Pinang, 11800 Malaysia. He is specialized in Open and Distance Learning Interactive Technologies and e-Learning (e-mail: rozhan@usm.my).

This work was supported in part by the Universiti Sains Malaysia under RU Grant 1001/PJJAUH/817015.

Manuscript received on December $28^{\text {th }}$, 2009. Published as resubmitted by the authors on June $29^{\text {th }}, 2010$. 